\title{
EFFECT OF PRETREATMENTS AND DRYING TEMPERATURES ON THE QUALITY OF DRIED PLEUROTUS MUSHROOM SPP.
}

\author{
HASSAN, F.R.H and GHADA M. MEDANY \\ Food Tech. Res. Inst., ARC, Giza, Egypt. \\ (Manuscript received 13 May 2014)
}

\begin{abstract}
This study was carried out to evaluate the effect of pretreatments prior drying as well as drying temperature on quality of the dried mushroom. Rehydration ratio and color of the dried product are the most effective parameter for judging and evaluating the drying process. Pleurotus ostreatus and Pleurotus eryngii samples were pretreated by different solutions ( $\mathrm{NaCl}$, citric acid and sodium metabisulfite) at room temperature and at $96 \pm 2$ ${ }^{\circ} \mathrm{C}$. Pretreated and control mushroom samples were dried by hot air at 50, 60 and $70^{\circ} \mathrm{C}$ until reached to constant weight. The dried product was evaluated immediately after drying. $P$. ostreatus required from 7-12 hr, while $P$. eryngii required $6.5-11 \mathrm{hr}$ to reach moisture content around $7 \%$ depending on pretreatment and drying temperature. Control sample dried by using any tested drying temperature recorded the highest rehydration ratio compared to other pretreated samples dried at the same drying temperature. Also, steeped dried samples had higher rehydration ratio than blanched ones. Samples steeped in sodium metabisulfite (SMS) prior drying had the lowest browning index, while those blanched in $\mathrm{NaCl}$ or citric acid had the highest browning index values. Drying process caused a considerable decrement in protein content and a severe reduction in total microbial counts of mushroom samples. Sensory evaluation revealed that control and samples steeped in SMS or $\mathrm{NaCl}$ prior drying at $50{ }^{\circ} \mathrm{C}$ got higher scores than the others. According to the results obtained it could be clearly concluded that, steeping $P$. ostreatus and $P$. eryngii samples in $\mathrm{NaCl}$, citric acid or Sodium metabisulfite $(0.1 \%$ each at room temperature) for $10 \mathrm{~min}$. prior drying at $50{ }^{\circ} \mathrm{C}$ prevented browning especially with SMS. Also, steeping treatment resulted satisfactory rehydration ratio for dried products even they were lower than the untreated (control) sample.

Keywords: Pleurotus ostreatus, Pleurotus eryngii, drying, pretreatment, rehydration ratio, browning index, sensory evaluation.
\end{abstract}

\section{INTRODUCTION}

The genus Pleurotus (oyster mushroom) comprises some most popular edible mushrooms due to their favourable organoleptic and medicinal properties, vigorous growth and undemanding difficult cultivation conditions. It can be cultivated on log and a wide variety of agroforestry (by-products), weeds and wastes for the production of food, feed, enzymes and medicinal compounds, or for waste degradation and detoxification. Its popularity has been increasing due to the ease of its cultivation on 
various unfermented lignocellulosic wastes, its high yield potential, high nutritional values, as well as medicinal values. Various Pleurotus species have been shown to possess a number of medicinal properties, such as antitumour, immunomodulatory, antioxidant, anti-inflammatory, hypocholesterolaemic, antihypertensive, antiplateletaggregating, antihyperglycaemic, antimicrobial and antiviral activities. These therapeutic activities are exhibited by extracts or isolated compounds from Pleurotus spp. fermentation broth, mycelia and fruiting bodies (Gregori et. al .2007).

Fresh mushrooms tend to lose quality after harvest, mainly because of their high respiration rate and the fact that they have no epidermis to protect them from water loss. Mushrooms' shelf-life is limited to a few days under normal refrigeration conditions, which is a constraint on the distribution and marketing of fresh product, making extension of mushroom's shelf life a constant quest (Akbarirad, et. a.l, 2013). Mushrooms are extremely perishable in nature and may not be kept for more than one day after harvesting at ambient conditions. Various physiological and morphological changes occur after harvest, which make these mushrooms unpalatable for consumption (Giri and Prasad, 2013) .

The mushrooms of the Pleurotus genus are more delicate and sensitive than the Agaricus genus and they start deteriorating immediately within one day after the harvest. Once deteriorated, these fruiting bodies can cause severe gastrointestinal discomfort (Lukasse and Polderdijk, 2003).

Drying is one of the important preservation techniques performed for storage of mushrooms and dehydrated mushrooms are valuable ingredients in a variety of food formulations such as instant soups, sauces, snacks, pizzas, and meat and rice dishes. Conventional air drying is one of the most frequently used techniques for mushroom dehydration, which involves thermal and /or chemical pretreatment and drying at temperature maintained between 50 and $70^{\circ} \mathrm{C}$. Due to long drying time and overheating of surface during hot air drying, the problems of darkening in colour, loss in flavour and decrease in rehydration ability occur. Freeze drying produces a high quality product, but being an expensive process, its application for mushroom drying is limited ( Giri and Prasad, 2013). Drying of oyster mushrooms can lengthen their shelf life and retain their properties plus quality as close to the original sample as possible. In conclusion, low heat air blow (LHAB) method is recommended in reducing water activity and increasing proximate contents ( Aishah and Wan Rosli, 2013) they also reported that, preserving mushroom in dried form can reduce the post harvest loss and extends their shelf life. Because of their high nutrient content, oyster mushroom powders can be incorporated in various recipes for improving the 
nutritional status of vulnerable population in developing countries (Muyanja, et. al., 2014).

The dehydrated mushrooms can be rehydrated by water immersion before the consumption. The rehydration characteristics of dried products are used as a quality parameter and are taken as indication for physical and chemical changes occurred during the drying process (Lewicki, 1998).

This study aimed to evaluate the effect of different pre- drying treatments and drying temperature on the quality of dried mushroom samples, which will define the optimum drying conditions for Pleurotus mushroom.

\section{MATERIALS AND METHODS}

Fresh mushroom fruit bodies of Pleurotus ostreatus (P 30) and Pleurotus eryngii ( $\mathrm{P}$ 008) were cultivated by the authors using the convenient cultivation method in Food Technology Research Institute (FTRI), Agricultural Research Center (ARC), Giza, Egypt in Dec. 2013. These mushroom types were obtained from Jun-Cao Research Institute, Fujian Agricultural \& Forestry University (FAFU), China.

\section{Samples preparation}

Undamaged fresh mushroom fruit bodies of uniform size and maturity (cap diameter, 7- $9 \mathrm{~cm}$ for P.ostreatus and stem diameter, $3.5-4.0 \mathrm{~cm}$ for $P$. eryngii) were selected. Mushroom fruit bodies were gently washed with tap water and adhering water was removed using tissue paper. $P$. ostreatus fruit bodies were vertically halved through the stem with sharp knife, while P.eryngii was cut into uniform discs $0.6-0.8 \mathrm{~mm}$. Samples of fruit bodies of each mushroom type were divided into 7 equal parts, each of them was subjected to one of the following treatments:

1- Control (untreated).

2- Steeping in sodium chloride ( $\mathrm{Nacl}) 0.1 \%$ at room temperature (at ratio of $500 \mathrm{ml}$. solution / $100 \mathrm{~g}$ sample) for $10 \mathrm{~min}$.

3- Steeping in citric acid $0.1 \%$ at room temperature (at ratio of $500 \mathrm{ml}$. solution / $100 \mathrm{~g}$ sample) for $10 \mathrm{~min}$.

4- Steeping in sodium metabisulphite (SMS) $0.1 \%$ at room temperature ( at ratio of $500 \mathrm{ml}$. solution / $100 \mathrm{~g}$ sample) for $10 \mathrm{~min}$.

5- Blanching in sodium chloride $0.1 \%$ at $96{ }^{\circ} \mathrm{C} \pm 2$ (at ratio of $500 \mathrm{ml}$. solution / $100 \mathrm{~g}$ sample) for $2.0 \mathrm{~min}$.

6- Blanching in citric acid 0.1 at $\% 96{ }^{\circ} \mathrm{C} \pm 2$ (at ratio of $500 \mathrm{ml}$. solution / $100 \mathrm{~g}$ sample) for $2.0 \mathrm{~min}$. 
7- Blanching in sodium metabisulphite (SMS) $0.1 \%$ at $96{ }^{\circ} \mathrm{C} \pm 2$ (at ratio of $500 \mathrm{ml}$. solution / $100 \mathrm{~g}$ sample) for $2.0 \mathrm{~min}$.

\section{Dehydration process}

The perforated Stainless Steel trays $(50 \times 50 \times 2 \mathrm{~cm})$ were loaded by pretreated mushroom samples and dried in an air ventilation oven at 50,60 and $70^{\circ} \mathrm{C} \pm$ 1 until reaching to constant weight. Drying time (hrs) for each treatment was recorded. Dried mushroom samples were chemically, physically and sensory analyzed immediately after drying process.

Browning index values and rehydration ratio of the dried mushroom were used as the basis to select the optimum drying treatment.

\section{Analysis Methods:}

\section{Rehydration Characteristics}

The rehydration ratio of dried mushroom samples was determined by soaking samples with a defined weight of water (approximately $5 \mathrm{~g}$ of mushroom in hot water of $300 \mathrm{~mL}$ at $85 \mathrm{C} \pm 5$ ). Rehydration was carried out till maximum weight of sample was obtained. The samples were then removed, dried off with tissue paper and weighed again. Rehydration ratio was defined as the ratio of weight of rehydrated samples to the dry weight of the sample (Arora et. al., 2003).

\section{Browning index}

The degree of non-enzymatic browning of the dried mushrooms was determined following the method of Mudahar and Bains (1982). The color was extracted from dried mushroom using $60 \%$ ethanol, and the absorbance of the filtrate was measured using a spectrophotometer at $440 \mathrm{~nm}$.

\section{Sensory evaluation:}

The quality attributes ( color, texture and taste) of fresh and dried (after being rehydrated) mushroom samples were organoleptically judged by a group of ten panelists. $100 \mathrm{~g}$ of each sample were sauteed in butter $(10 \mathrm{~g})$, salted then served. as reported by Komanowsky et. al. (1970). These qualities were scored on a scale of one to ten.

\section{Chemical analysis:}

Moisture, crude protein $(\mathrm{N} \times 6.25)$, contents were determined according to the A.O.A.C (2005).

\section{Microbilogical test:}

Total microbial count was estimated on both fresh and dried mushrooms immediately after drying. Total microbial count was enumerated on plate count agar medium. 


\section{Statistical analysis}

The obtained data throughout the course of this study were expressed as means of replicates and statistically analyzed using ANOVA procedure of the SPSS statistical package at confidence level of (0.05) (SPSS, 1990).

\section{RESULTS AND DISCUSSION}

Data represented in Table (1) show that, drying time was distinctly affected by drying temperature with reversely correlation, while pre treatment caused a little effect in that tested item. Drying time ranged between $7.0-12.0 \mathrm{hr}$ for $P$. ostreatus and $6.5-11.0 \mathrm{hr}$ for $P$. eryngii for all drying temperature and pretreatments. It could be observed that, control (untreated) showed the shortest drying time at any drying temperature, while blanching pretreatment seems to elongate drying time compared to control or steeped ones.

These results are confirmed by the findings of many authors, drying time was (10.5, 9.5 and 8.5) for Agaricus bisporus mushroom dried ,while it was (8.0, 7.0 and $6.5 \mathrm{hr}$ ) for Pleurotus florida at 50, 55 and $60^{\circ} \mathrm{C}$, respectively (Arora et. al., 2003), the time required to reduce the moisture content of P.ostreatus mushrooms from the initial value of $90.12 \%$ to a final value about $10 \%$ were 480,360 and 300 min at 50, 60 and $70{ }^{\circ} \mathrm{C}$, respectively (Tulek, 2011); Drying time for Agaricus bisporus by medium size solar drier was 13-14 hr, while for open sun drying was 19- $20 \mathrm{hr}$ (Kumar et. al., 2013). 
Table 1. Effect of pretreatments and drying temperatures on drying time, rehydration ratio and color index of Pleurotus mushroom.

\begin{tabular}{|c|c|c|c|c|c|c|}
\hline & \multicolumn{3}{|c|}{ P.ostreatus } & \multicolumn{3}{|c|}{ P. eryngii } \\
\hline & $\begin{array}{l}\text { Drying } \\
\text { time } \\
\text { (hrs) }\end{array}$ & Reh. ratio & Browning index & $\begin{array}{c}\text { Drying } \\
\text { time (hrs) }\end{array}$ & Reh. ratio & Browning index \\
\hline & \multicolumn{6}{|c|}{ Drying at $50^{\circ} \mathrm{C}$} \\
\hline Control & 10.0 & $6.36 \mathrm{a} \pm 0.57$ & $0.217 \mathrm{gh} \pm 0.02$ & 10.0 & $5.56 a \pm 0.49$ & $0.230 \mathrm{k} \pm 0.01$ \\
\hline \multicolumn{7}{|l|}{ Steeping } \\
\hline $\mathrm{NaCl}$ & 10.5 & $5.31 \mathrm{bcd} \pm 0.72$ & $0.245 \mathrm{~g} \pm 0.02$ & 10.5 & $5.0 \mathrm{~b} \pm 0.14$ & $0.294 \mathrm{fg} \pm 0.03$ \\
\hline Citric acid & 11.0 & $5.32 \mathrm{bcd} \pm 0.48$ & $0.224 \mathrm{gh} \pm 0.01$ & 10.0 & $4.93 \mathrm{~b} \pm 0.15$ & $0.287 \mathrm{fg} \pm 0.03$ \\
\hline SMS & 11.0 & $5.57 \mathrm{bc} \pm 0.25$ & $0.172 \mathrm{k} \pm 0.03$ & 10.0 & $4.96 \mathrm{~b} \pm 0.38$ & $0.184 \mathrm{~L} \pm 0.01$ \\
\hline \multicolumn{7}{|l|}{ Blanching } \\
\hline $\mathrm{NaCl}$ & 12.0 & $3.12 f \pm 0.23$ & 0.311 ef \pm 0.04 & 10.5 & $2.96 \mathrm{e} \pm 0.52$ & $0.303 \mathrm{fg} \pm 0.02$ \\
\hline Citric acid & 12.0 & $2.61 f \pm 0.20$ & $0.291 \mathrm{f} \pm 0.01$ & 11.0 & $2.22 \mathrm{f} \pm 0.15$ & $0.306 \mathrm{fg} \pm 0.03$ \\
\hline SMS & 11.5 & $3.34 \mathrm{f} \pm 0.41$ & $0.201 \mathrm{hk} \pm 0.02$ & 11.0 & $2.52 \mathrm{ef} \pm 0.25$ & $0.218 \mathrm{~kL} \pm 0.03$ \\
\hline & \multicolumn{6}{|c|}{ Drying at $60^{\circ} \mathrm{C}$} \\
\hline Control & 9.0 & $5.61 \mathrm{~b} \pm 0.40$ & $0.287 f \pm 0.01$ & 8.5 & $4.90 \mathrm{~b} \pm 0.28$ & $0.301 \mathrm{fg} \pm 0.01$ \\
\hline \multicolumn{7}{|l|}{ Steeping } \\
\hline $\mathrm{NaCl}$ & 9.5 & 5.02 bcde \pm 0.43 & 0.323 ef \pm 0.03 & 9.0 & $4.78 \mathrm{bc} \pm 0.07$ & $0.361 \mathrm{de} \pm 0.01$ \\
\hline Citric acid & 10.0 & 4.83 cde \pm 0.29 & $0.341 \mathrm{ef} \pm 0.04$ & 9.0 & $4.36 \mathrm{~cd} \pm 0.31$ & $0.325 \mathrm{ef} \pm 0.04$ \\
\hline SMS & 9.5 & 4.96 bcde \pm 0.30 & $0.203 \mathrm{hk} \pm 0.01$ & 9.5 & $4.14 d \pm 0.30$ & $0.273 \mathrm{hj} \pm 0.02$ \\
\hline \multicolumn{7}{|l|}{ Blanching } \\
\hline $\mathrm{NaCl}$ & 10.0 & $2.76 f \pm 0.59$ & $0.395 d \pm 0.02$ & 9.5 & $2.45 \mathrm{ef} \pm 0.15$ & $0.491 \mathrm{~b} \pm 0.01$ \\
\hline Citric acid & 11.0 & $2.51 \mathrm{f} \pm 0.34$ & $0.391 d \pm 0.02$ & 10.0 & $2.39 \mathrm{f} \pm 0.24$ & $0.407 c \pm 0.04$ \\
\hline \multirow[t]{2}{*}{ SMS } & 10.5 & $2.88 \mathrm{f} \pm 0.21$ & $0.213 \mathrm{gh} \pm 0.02$ & 9.5 & $2.13 \mathrm{f} \pm 0.13$ & $0.248 \mathrm{jk} \pm 0.01$ \\
\hline & \multicolumn{6}{|c|}{ Drying at $70^{\circ} \mathrm{C}$} \\
\hline Control & 7.0 & $5.08 \mathrm{bcde} \pm 0.26$ & $0.418 \mathrm{~d} \pm 0.02$ & 6.5 & $3.88 \mathrm{~d} \pm 0.41$ & $0.385 \mathrm{~cd} \pm 0.02$ \\
\hline \multicolumn{7}{|l|}{ Steeping } \\
\hline $\mathrm{NaCl}$ & 8.5 & 4.78de \pm 0.44 & $0.427 \mathrm{~cd} \pm 0.02$ & 7.0 & $3.96 \mathrm{~d} \pm 0.36$ & $0.481 \mathrm{~b} \pm 0.02$ \\
\hline Citric acid & 8.5 & $4.36 \mathrm{e} \pm 0.60$ & $0.460 \mathrm{bc} \pm 0.02$ & 7.0 & $4.02 \mathrm{~d} \pm 0.38$ & $0.503 b \pm 0.01$ \\
\hline SMS & 7.5 & 4.80cde \pm 0.29 & $0.218 \mathrm{gh} \pm 0.02$ & 7.5 & $3.9 d \pm 0.30$ & $0.236 \mathrm{jk} \pm 0.02$ \\
\hline \multicolumn{7}{|l|}{ Blanching } \\
\hline $\mathrm{NaCl}$ & 8.0 & $2.43 f \pm 0.38$ & $0.484 a b \pm 0.02$ & 7.5 & $2.08 \mathrm{f} \pm 0.29$ & $0.570 \mathrm{a} \pm 0.03$ \\
\hline Citric acid & 8.5 & $2.60 f \pm 0.29$ & $0.507 a \pm 0.02$ & 8.0 & $2.0 \mathrm{f} \pm 0.28$ & $0.571 \mathrm{a} \pm 0.02$ \\
\hline SMS & 8.0 & $2.58 \mathrm{f} \pm 0.36$ & $0.230 \mathrm{gh} \pm 0.02$ & 8.0 & $2.17 f \pm 0.24$ & $0.350 \mathrm{de} \pm 0.01$ \\
\hline
\end{tabular}

Values represented as means of replicates \pm SD.

Browning index for fresh $P$. ostretus was 0.011 and for $P$. eryngii was 0.016 .

Values in the same column following by the same superscript are not significantly different at (p. $\leq 0.05)$.

Higher rehydration ratio indicates better dried product. Rehydration ratio was severely affected by pretreatment with a slight effect caused by drying temperature or mushroom type (Table, 1$)$. Generally, high drying temperature $\left(70^{\circ} \mathrm{C}\right)$ exhibited low rehydration values $(2.43-5.08)$ and (2.0-3.88), vice versa low drying temperature $\left(50^{\circ} \mathrm{C}\right)$ showed higher rehydration values $(3.12-6.36)$ and $(2.22-5.56)$ for $P$. ostreatus and $P$. eryngii, respectively. Blanching mushroom samples in different tested solution prior drying resulted in the lowest rehydration values which highly significant differed compared to the control or those steeped in the same solution at room temperature, this was more pronounced at higher drying temperature $\left(60\right.$ and $\left.70^{\circ} \mathrm{C}\right)$. 
The rehydration ratio values of blanched mushroom samples in different tested solutions prior drying were $(2.43-2.60),(2.51-2.88)$ and $(2.61-3.43)$ for $P$. ostreatus, without significant differences in between, when dried at 70,60 and $50{ }^{\circ} \mathrm{C}$, respectively. Moreover, the same trend was detected for $P$. eryngii mushroom samples which subjected to blanching in the tested solutions prior drying at 70,60 and $50{ }^{\circ} \mathrm{C}$ being $(2.0-2.17),(2.13-2.45)$ and $(2.22-2.96)$ in succession, without significant differences. Meanwhile, steeping mushroom samples of $P$. ostreatus in the different tested solutions prior drying at 70,60 and $50{ }^{\circ} \mathrm{C}$ showed high rehydration ratio values being $(4.36-4.80),(4.83-5.02)$ and $(5.31-5.57)$, respectively. Also, the rehydration ratio values for $P$. eryngii mushroom samples steeped in different solution prior drying at 70,60 and $50{ }^{\circ} \mathrm{C}$ were $(3.90-4.02),(4.14-4.78)$ and $(4.93-$ $5.0)$, respectively. Rehydration ratio values of steeped mushroom samples in the tested solutions prior drying were much higher than the blanched ones for each drying temperature used. Control (untreated) samples for the two tested mushrooms recorded the highest rehydration ratio values being $(5.08,5.61$ and 6.36$)$ for $P$. ostreatus and $(3.88,4.90$ and 5.56$)$ for $P$. eryngii when dried at 70,60 and $50{ }^{\circ} \mathrm{C}$. in succession.

Control dried sample at $50^{\circ} \mathrm{C}$ for $P$. ostreatus and $P$. eryngii had the highest rehydration values (6.36 and 5.56) and differed significantly compared to the other dried samples. Also, it could be noticed that mushroom samples treated by steeping in the tested solutions for $10 \mathrm{~min}$. at room temperature prior drying at $50^{\circ} \mathrm{C}$ had high and fairly good rehydration ratio values without significant differences. It is worthy mentioned that, dried mushroom products of control, steeped in different tested solutions prior drying at $50^{\circ} \mathrm{C}$ showed their fully rehydration capacity ( maximum water absorption) through only $20 \mathrm{~min}$. even by using cold water, while, blanched ones showed very poor rehydration values even in hot water $\left(85^{\circ} \mathrm{C} \pm 5\right)$ for 90 min (unrecorded data).

It could be noticed that rehydration ratio for $P$. ostreatus were higher than those of P.eryngii at the same drying conditions and this may be attributed to the differences in tissue structures of the mushroom portion used. The stem represents the most used portion in P. eryngii with a little small cap, hence, stems usually compact and more fibrous than the cap. In contrast, the main used portion of P.ostreatus is the cap.

The poor rehydration ratio of blanched samples could be due to the effect of heat treatment on the protein structure and the permeability of the cell walls of the mushrooms. In this respect Konanayakam, and Sastry, 1988) stated that, blanching with hot water or steam at high temperature causes undesirable changes in product 
texture and also inherently linked to weight and nutritional quality losses in the product. Riaz et. al. (1991) concluded that untreated (control) dried mushroom samples, were higher in rehydration ratio compared to blanched ones. They also stated that blanching as pre-treatment yielded structurally more compact product after drying and this factor adversely influenced the rehydration of blanched mushrooms. Jayathunge and Illeperuma (2001) declared that, the higher rehydration ratio observed in their study may probably be due to minimum changes in the structure of proteins and consequently minimum changes in protein functionality at the low drying temperature of $45^{\circ} \mathrm{C}$. Kumar et. al., (2013) recorded that, the mushrooms dried in medium size dryer using pretreatment of $1.0 \%$ potassium metabisulphite gave the maximum rehydration ratio and coefficient of rehydration.

Increasing drying temperature increased firmness of the product probably because the mushrooms dried faster thus the time for the breakdown of the cell structural components like pectin or cellulose were reduced (Mohamed and Hoo (1994). Kulshreshtha et. al (2009) mentioned that, the rehydration ratio of dried samples was higher at the lower drying temperatures and was the highest at $50^{\circ} \mathrm{C}$. Rehydration ratio ranged from 2.563 to 4.015 for different operating conditions. Nour et. al. (2011) found that, the sliced button mushrooms dried at lower temperature had greater rehydration ratio as compared with the sample dried at higher temperature. They stated that, at lower temperatures, less cellular destruction and dislocation occur thus, the material is capable of absorbing more water. Apati et. al., (2010) stated that, the rehydration capacity decreased with increasing drying temperature, which could be associated to the stronger mushroom structure deformation at higher temperatures. The minimum rehydration ratio of 2.18 was obtained for blanched slices treated.

Browning index values were represented as absorbance at $440 \mathrm{~nm}$. The absorbance value for fresh $P$. ostretus was 0.011 and for $P$. eryngii was 0.016 which increased by different manners according to pretreatment and drying temperature (Table, 1). Generally, pretreated mushroom samples with sodium metabisulphite (SMS) either by steeping or blanching retarding browning. Meanwhile, treated Pleurotus mushroom samples by citric acid or sodium chloride $(\mathrm{NaCl})$ either by steeping or blanching showed higher browning index values which more obvious with blanching prior drying and/or at higher drying temperature. The lowest browning index values ( 0.172 and 0.184 ) were recorded to SMS steeped mushroom samples and followed by $(0.201$ and 0.218$)$ without significantly differences for blanched with SMS prior drying at $50^{\circ} \mathrm{C}$ for $P$. ostreatus and $P$. eryngii, respectively. Control samples dried at $50^{\circ} \mathrm{C}$ came in second order for browning index after SMS treatment for the 
two mushroom types. Also, it could be noticed that samples of both mushroom spp. treated by steeping in $\mathrm{NaCl}$ and citric acid prior drying at $50{ }^{\circ} \mathrm{C}$ resulted low absorbance (at 440nm) and adequate light color. The highest browning index values ( 0.507 and 0.484$)$ and $(0.571$ and 0.570$)$ for $P$. ostreatus and $P$. eryngii, were those blanched in citric and $\mathrm{NaCl}$ and dried at $70^{\circ} \mathrm{C}$ without significant differences in between, while they highly significant differed than other samples. It could be observed that blanching in citric or $\mathrm{NaCl}$ prior drying especially when using high drying temperature significantly increased browning index values for $P$. ostreatus and $P$. eryngii.

Darkening or browning of dried mushrooms could be attributed mainly to enzymatic browning, Millard reactions, oxidation of phenolic compounds or microbial activities. In this respect, Komanowsky et. al., (1970) revealed that, mushroom varieties discoloration was proportional to the amount of heat treatment and lower drying temperatures yielded lighter product. Blanching for $10 \mathrm{~min}$. caused excessive darkening during drying. Visual inspection revealed that pretreatment of mushroom pieces with citric acid, table salt, ascorbic acid, EDTA or sodium acid pyrophosphate had little effect on color of dried mushroom. Among the chemical tested for pretreatment, only sodium bisulfite was found to decease mushroom discoloration during drying. They also concluded that, blanched mushrooms darken when they are exposed to hot air during drying. Products with good flavor, storage stability and a better color and shape were obtained by dehydrated unblanched mushrooms.

Sodium chloride $(0.1 \%)$ was not effective in improving the colour of Pleurotus spp. Though $0.1 \%$ potassium metabisulphite improved the colour. Dehydration at $60^{\circ} \mathrm{C}$ for $7 \mathrm{~h}$ resulted in a product that was somewhat dark in colour and extremely shrunk. Meanwhile, drying at $45^{\circ} \mathrm{C}$ was found to be the best as it produced the lightest and the least shrunk dehydrated product (Jayathunge and Illeperuma, 2001). Generally the browning of the dried mushroom product is more pronounced at higher temperatures (Kulshreshtha et. al., 2009). The total colour change was greater in the samples dried at higher temperature. This implies that with increase in air temperature, the degradation rate of colour becomes faster as a result of high energy transferred to the inside of food material. The main factor causing colour changes during hot-air drying is enzymatic and non-enzymatic browning reactions. Lowering the drying air temperature resulted in lower thermal stress on the surface and a higher whiteness index was obtained (Nour et. al., 2011). It was statistically proved that the pretreatment with $0.5 \%$ potassium metabisulphite $+0.2 \%$ citric acid gave the poor results. The mushrooms dried in medium size dryer using pretreatment of $1.0 \%$ 
potassium metabisulphite gave the maximum values of whiteness (Kumar et. al., 2013).

According to the results of rehydration ratio and browning index obtained from Table (1) it could be clearly recommended that, control (untreated) and steeped in citric acid, $\mathrm{NaCl}$ or SMS prior drying at $50^{\circ} \mathrm{C}$ are the optimum drying conditions for $P$. ostreatus and $P$. eryngii mushroom from quality point of view. So, only the aforementioned samples were selected to complete the course of this investigation.

\section{Moisture, protein content and total microbial count of dried mushrooms:}

Samples of P.ostreatus and P.eryngii treated by steeping in NaCl, Citric acid and SMS as well as control(untreated) prior drying by hot air at $50 \mathrm{C}$ were analyzed for moisture , crude protein and total microbial counts immediately after drying. Moisture content of mushroom samples dropped from 89.38 and $86.45 \%$ for fresh to be $(7.61-7.93 \%)$, and (7.73- 7.92\%) without significant differences for dried ones at $50{ }^{\circ} \mathrm{C}$ for P.ostreatus and P.eryngii, respectively (Table,2). A decrease pattern in protein content of P.ostreatus and P.eryngii caused by drying process was detected. A slight decrease in protein content ( 2.6 and $2.14 \%$ ) for the control dried samples of P.ostreatus and P.eryngii was found, while this decrement was more pronounced for samples steeped in citric acid and $\mathrm{NaCl}$ (10.1 and $9.11 \%)$ and (9.37 and 8.31\%), respectively. Sulfured samples (SMS steeping) recorded moderate loss in protein content (Table, 2). Almost no significant loss in protein content for control or SMS steeped dried samples compared to fresh samples of the two tested mushroom types.

Table 2 .Effect of drying at $50{ }^{\circ} \mathrm{C}$ on moisture\%, crude protein $\%$ and total microbial count of Pleurotus mushroom.

\begin{tabular}{|l|c|c|c|c|c|c|}
\hline & \multicolumn{3}{|c|}{ Pleurotus ostreatus } & \multicolumn{3}{c|}{ Pleurotus eryngii } \\
\hline & Moisture\% & $\begin{array}{c}\text { Crude } \\
\text { protein } \%\end{array}$ & CFU $\times 10^{3} / \mathrm{g}$ & Moisture\% & Crude & CFU $\times 10^{3} / \mathrm{g}$ \\
protein $\%$ & \\
\hline Fresh & 89.38 & $29.52^{\mathrm{a}} \pm 1.45$ & $4.9^{\mathrm{a}} \pm 0.300$ & 86.45 & $25.61^{\mathrm{a}} \pm 0.968$ & $3.8^{\mathrm{a}} \pm 0.557$ \\
\hline Control & $7.61^{\mathrm{a}} \pm 0.360$ & $28.74^{\mathrm{ab}} \pm 1.54$ & $1.8^{\mathrm{b}} \pm 0.624$ & $7.73^{\mathrm{a}} \pm 0.223$ & $25.06^{\mathrm{ab}} \pm 0.874$ & $1.8^{\mathrm{b}} \pm 0.361$ \\
\hline NaCl & $7.93^{\mathrm{a}} \pm 0.491$ & $26.83^{\mathrm{b}} \pm 1.18$ & $1.7^{\mathrm{b}} \pm 0.361$ & $7.86^{\mathrm{a}} \pm 0.271$ & $23.48^{\mathrm{c}} \pm 0.704$ & $1.6^{\mathrm{bc}} \pm 0.265$ \\
\hline Citric & & & & & & \\
acid & $7.84^{\mathrm{a}} \pm 0.096$ & $26.55^{\mathrm{b}} \pm 1.14$ & $1.4^{\mathrm{bc}} \pm 0.265$ & $7.89^{\mathrm{a}} \pm 0.356$ & $23.21^{\mathrm{c}} \pm 0.399$ & $1.3^{\mathrm{bc}} \pm 0.173$ \\
\hline SMS & $7.71^{\mathrm{a}} \pm 0.290$ & $27.71^{\mathrm{ab}} \pm 0.365$ & $1.3^{\mathrm{c}} \pm 0.436$ & $7.92^{\mathrm{a}} \pm 0.251$ & $24.06^{\mathrm{bc}} \pm 0.917$ & $1.1^{\mathrm{d}} \pm 0.265$ \\
\hline
\end{tabular}

Values represented as means of replicates \pm SD.

Values in the same column following by the same superscript are not significantly different at (p. $\leq 0.05)$.

These results for moisture are lower than those obtained by Kulshreshtha et. al. (2009) who recorded that, milky mushroom slices were dried from an initial moisture content of approximately $90 \%$ to the final moisture content of about $10 \%$ in 
a fluidized bed dryer. Nour et. al., (2011) declared that, the moisture content of the fresh button mushrooms (both untreated and treated samples) was found in range of 90-91\% which reduced to $9-12 \%$ after tray drying for various temperatures of air drying. Also Tulek (2011) found that, the final moisture content of dried P.ostreatus was $10 \%$.

The lower protein content of dried oyster mushroom may be due to leaching out during steeping and/or loss throughout browning reactions. Many authors confirmed these findings. Blanching mushrooms with hot water or steam at high temperature causes undesirable changes in product texture and also inherently linked to weight and nutritional quality losses (Konanayakam, and Sastry, 1988). The lower protein content of dried oyster mushrooms could be explained by the much greater protein solubilization during brining for a longer time (Muyanja et. al., 2014).

Drying process caused a dramatically decrease in total microbial count, which dropped from $4.9 \mathrm{CFU} \times 10^{3} / \mathrm{g}$ to be ranged from $1.3-1.8 \mathrm{CFU} \times 10^{3} \mathrm{~g}$ for P.ostreatus and from $3.8 \mathrm{CFU} \times 10^{3} / \mathrm{g}$ to $\left(1.1-1.8 \mathrm{CFU} \times 10^{3} / \mathrm{g}\right)$ for $P$. eryngii . Among dried mushroom samples, SMS steeped samples showed the lowest total microbial count, while control samples were on the contrary (Table, 2). In this respect, Komanowwsky et. al. (1970) stated that, fresh mushroom of good quality have over one million bacteria $/ \mathrm{g}$. After drying the total bacterial colonies/g were ranged between $5-8.60 \times 10^{3}$ according to drying conditions and sulfitation (200 ppm $\mathrm{SO}_{2}$ ) prior drying recorded the lowest counts . Lakshmipathy et. al., (2013) reported that, open sun dried mushrooms had a significant higher number of microorganisms than all other dehydrated mushrooms. Higher moisture content of the open dried mushroom compared to other dryers could have influenced the microorganism on the dried mushrooms. The objective of drying is to remove water to a level at which microbial spoilage and deterioration reactions are greatly minimized.

\section{Sensory evaluation of mushroom samples:}

Data presented in table (3) declare that, fresh mushroom samples of P.ostreatus and P.eryngii got the highest scores for the all tested sensory attributes and differed significantly than other dried ones. As for color of dried tested mushrooms steeped in SMS got the highest score and ranked the second order after fresh followed by control samples. Pretreated P.ostreatus and P.eryngii mushroom with citric acid and $\mathrm{NaCl}$ didn't improve the product color. Texture seems to be greatly affected by pretreatment, control dried sample got the highest score and differed significantly than the others and come in the second order after fresh samples for both mushroom types and followed by SMS treated samples. Regarding taste of dried mushroom the obtained sensory data show that, control and $\mathrm{NaCl}$ steeped samples got acceptable 
score and differed significantly compared to other samples. It could be noticed that, SMS treated and dried samples were superior in color, while control samples get the highest score in texture and taste followed by those steeped in $\mathrm{NaCl}$.

Table 3. sensory evaluation of fresh and dried mushrooms at $50^{\circ} \mathrm{C}$.

\begin{tabular}{|l|c|c|c|c|c|c|}
\hline \multirow{2}{*}{} & \multicolumn{3}{|c|}{ Pleurotus ostreatus } & \multicolumn{3}{c|}{ Pleurotus eryngii } \\
\cline { 2 - 7 } & color & texture & Taste & color & texture & taste \\
\hline Fresh & $9.5^{\mathrm{a}} \pm 0.527$ & $9.2^{\mathrm{a}} \pm 0.537$ & $9.6^{\mathrm{a}} \pm 0.394$ & $9.3^{\mathrm{a}} \pm 0.483$ & $9.8^{\mathrm{a}} \pm 0.258$ & $9.7^{\mathrm{a}} \pm 0.349$ \\
\hline Control & $7.8^{\mathrm{b}} \pm 0.823$ & $8.4^{\mathrm{b}} \pm 0.737$ & $8.2^{\mathrm{b}} \pm 0.483$ & $8.0^{\mathrm{c}} \pm 0.408$ & $8.6^{\mathrm{b}} \pm 0.567$ & $8.8^{\mathrm{b}} \pm 0.483$ \\
\hline $\mathrm{NaCl}$ & $6.7^{\mathrm{c}} \pm 0.483$ & $6.4^{\mathrm{d}} \pm 0.567$ & $7.8^{\mathrm{c}} \pm 0.349$ & $6.3^{\mathrm{d}} \pm 0.714$ & $6.3^{\mathrm{d}} \pm 0.333$ & $7.6^{\mathrm{c}} \pm 0.516$ \\
\hline Citric acid & $5.3^{\mathrm{d}} \pm 0.948$ & $6.9^{\mathrm{cd}} \pm 0.843$ & $6.2^{\mathrm{d}} \pm 0.421$ & $5.2^{\mathrm{e}} \pm 0.537$ & $6.0^{\mathrm{e}} \pm 0.408$ & $6.7^{\mathrm{d}} \pm 0.421$ \\
\hline SMS & $8.1^{\mathrm{b}} \pm 0.809$ & $7.2^{\mathrm{c}} \pm 0.789$ & $6.4^{\mathrm{d}} \pm 0.516$ & $8.7^{\mathrm{b}} \pm 0.483$ & $7.0^{\mathrm{c}} \pm 0.258$ & $6.5^{\mathrm{d}} \pm 0.459$ \\
\hline
\end{tabular}

Values represented as means of replicates \pm SD.

Values in the same column following by the same superscript are not significantly different at (p. $\leq 0.05)$.

Kulshreshtha et. al. (2009) stated that, drying air temperature of $50{ }^{\circ} \mathrm{C}$ is better as it gives dried product with higher rehydration ratio, lower shrinkage and better color. Drying of oyster mushrooms using Low Heat Air Blow method can lengthen their shelf life and retain their properties plus quality as close to the original sample as possible (Aishah and Wan Rosli, 2013). Arora et. al., (2003) reported that, sulphitation prior to drying is usually carried out to control non-enzymatic browning in order to improve acceptability of the products.

\section{CONCLUSION}

According to the obtained results throughout this course of study, it could be concluded that, pretreated $P$. ostreatus and P.eryngii by steeping in SMS, $0.1 \%$ at room temperature improved product color and microbiological aspects significantly, also retained important nutrients. Control samples had the highest rehydration ratio. Also steeping tested mushroom samples in $\mathrm{NaCl}$ or citric acid $(0.1 \%$ each for $10 \mathrm{~min}$. at room temperature) gave fairly good results even they are less than those treated with SMS. Blanching as pretreatment is not suitable for improving dried mushroom quality. Also, among drying temperatures, hot air at $50{ }^{\circ} \mathrm{C}$ was the ideal and resulted in good quality mushroom product. 


\section{REFERENCES}

1. Aishah, M.S. and Wan Rosli, W.I. 2013. Effect of Different Drying Techniques on the Nutritional Values of Oyster Mushroom (Pleurotus sajor-caju). Sains Malaysiana 42(7):937-941.

2. Akbarirad, H ; Kazemeini,S.M, and Shariaty, M.A. 2013. Deterioration and some of applied preservation techniques for common mushrooms (Agaricus bisporus, followed by Lentinus edodes, Pleurotus spp.). Journal of Microbiology, Biotechnology and Food Sciences 2 (6) 2398-2402.

3. AOAC., 2005. Official methods of analysis (18th ed.). Published by the Association of Official Analytical Chemist's International, Published by AOAC International suite 500481 North Fredrick Avenue Gaithersburg, Maryland 208772417, USA

4. Apati, G. P.; Sandra Aparecida Furlan, S.A. and João Borges Laurindo, J.B. 2010. Drying and Rehydration of Oyster Mushroom. Brazilian Archives Of Biology And Technology, Vol.53, ( 4): 945-952.

5. Arora, S. ; Shivhare, U. S. ; Ahmed, J. and Raghavan, G. S. V. 2003. Drying kinetics of Agaricus bisporus and Pleurotus florida mushrooms. American Society of Agricultural Engineers, 46(3): 721-724

6. Giri, S.K and Prasad, S. 2013. Quality Characteristics of Microwave-Vacuum Dried mushrooms. Octa. J. Biosci. Vol. 1(1):24-31

7. Gregori ,A.; Svagelj, M. and Pohleven,J. 2007. Cultivation Techniques and medicinal Properties of Pleurotus spp. Food Technol. Biotechnol. 45 (3) 238-249.

8. Jayathunge, K.G.L.R. and Illeperuma, C.K.(2001). Dehydration of Oyster Mushroom and Studies on Acceptability and Storability of the Product. Tropical Agricultural Research,. 13:69-77.

9. Komanowsky, M.; Talley, F.B. and Eskew, R.K. 1970. Air drying of cultivated mushrooms. Food technology 24: 1020-1024.

10. Konanayakam, M. and Sastry, S.K. 1988. Kinetics of shrinkage of mushrooms during blanching, Journal of Food Science 53 (1988) 1406-1411.

11. Kulshreshtha, M.; Singh,A. and Vipul, D. 2009. Effect of drying conditions on mushroom quality. Journal of Engineering Science and Technology 4 (1) : 90 98

12. Kumar, A. ; Singh, M. and Singh, G. 2013. different pretreatments on the quality of mushrooms during solar drying , Food Sci Technol ,50(1):165- 170. 
13. Lakshmipathy,G; Jayakumar, A; abhilash, M and Raj, S.P. 2013. Studies on different drying, canning and value addition techniques for mushrooms (Calocybe Indica). Afr. J. Food Sci., 7 (10): 361- 367.

14. Lewicki, P.P. 1998. Some Remarks on Rehydration of Dried Foods. J. Food Eng., 36, 81-87.

15. Lukasse, L.J.S.; Polderdijk, J.J. 2003. Predictive modelling of post-harvest quality evolution in perishables, applied to mushrooms. J. Food Eng., 59: 191-198.

16. Mohamed, S. and Hoo, T.S. 1994. Effect of Pretreatments on the Characteristics of Dried Grey Oyster Mushroom (Pleurotus sajor - caju). Pertanika J. Trop. Agric. Sci. 17(2): 111-115.

17. Mudahar, G. S., and Bains. S. 1982. Pretreatment effect on quality of dehydrated Agaricus bisporus mushroom. Indian Food Packer 36(3): 19-27.

18. Muyanja,C.;Kyambadde, D.and Namugumya, B. 2014. Oyster mushroom (Pleurotus ostreatus) powder and soup. Journal of Food Processing and Preservation 38, 457-465

19. Nour, V.; Trandafir, I. and Ionica, M.E. 2011. Effects of pre-treatments and drying temperatures. South Western Journal of Horticulture, Biology and Environment, .2, (1): 5-24.

20. Riaz, R.A.; Khan, S.M, and Bhatti, M.A. 1991. Effect of blanching and storage on the quality of the dehydrated oyster mushrooms (Pleurotus ostreatus). Mushroom J. Tropics, 11: 39.

21. SPSS, 1990. SPSS /PC for the IBMPC/XI. Chicago, IL. USA.

22. Tulek, Y. 2011. Drying Kinetics of Oyster Mushroom (Pleurotus ostreatus) in a Convective Hot Air Dryer. J. Agr. Sci. Tech., 13: 655-664. 
تاثير المعاملات الاولية وحرارة التجفيف على جودة مشروم البلورتس المجفف.

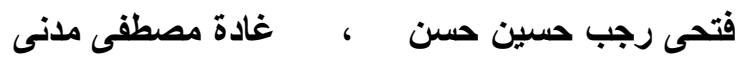

$$
\begin{aligned}
& \text { معهُ بحوث تكنولوجيا الاغذية - مركز البحوث الزراعية- الجيزة- مصر }
\end{aligned}
$$

اجريت هذة الدراسة لتقييم تاثير المعاملات الاولية قبل التجفيف و وكذلك درجـات حـر ارة

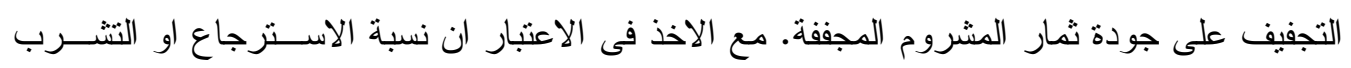

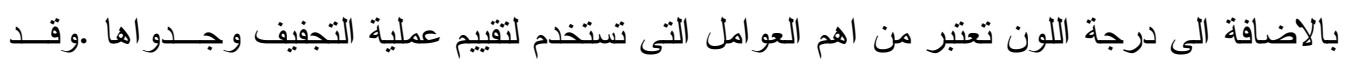
جرى فى هذا البحث معاملة ثمار مشروم البلوروتس اوسترينس و البلوروتس ارينجى بمحاليل مختلفة

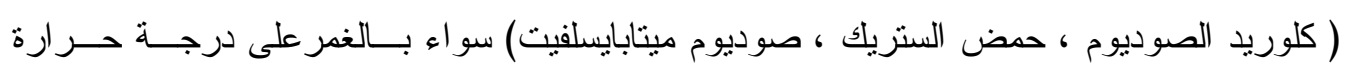

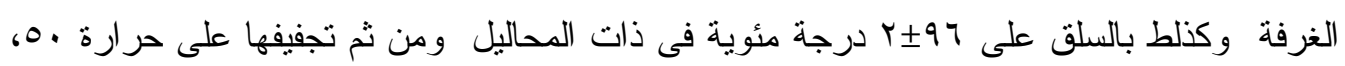

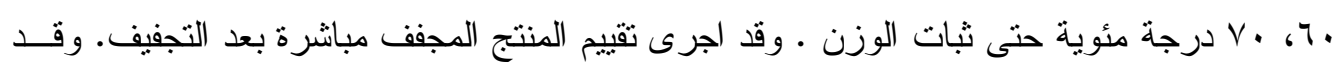

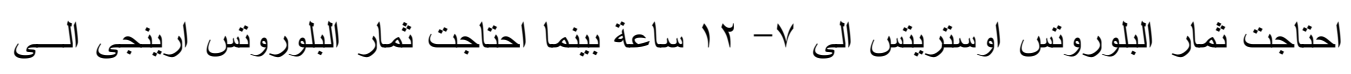

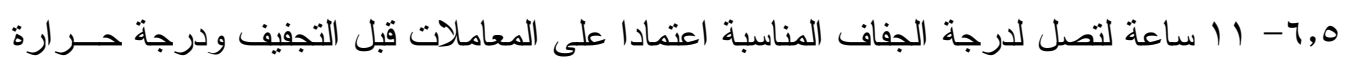

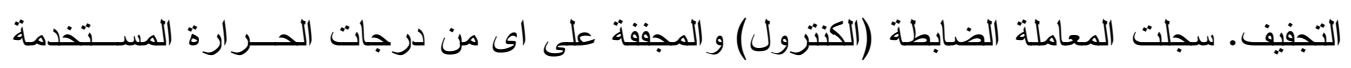

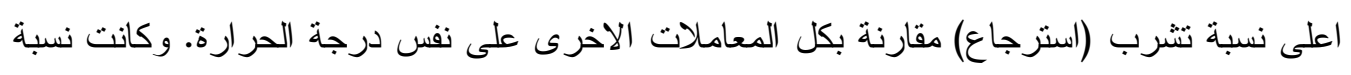

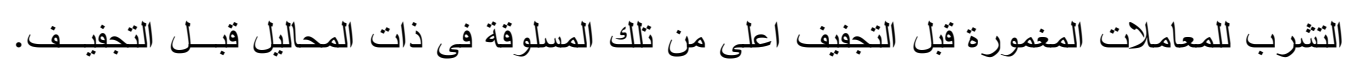

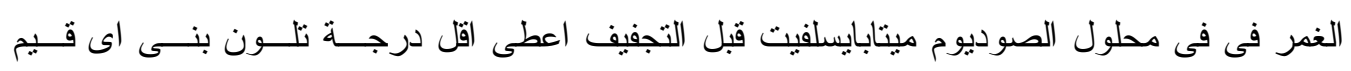

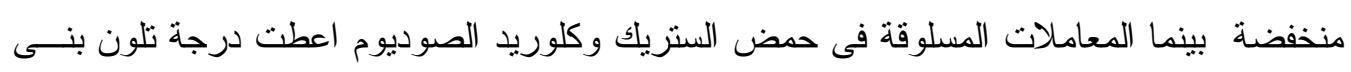

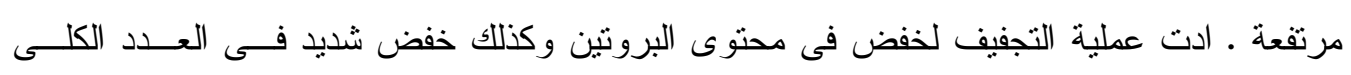

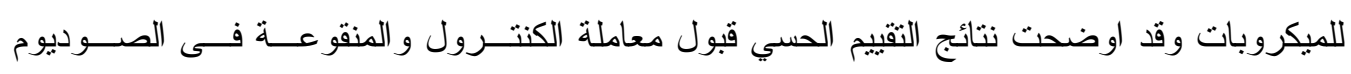

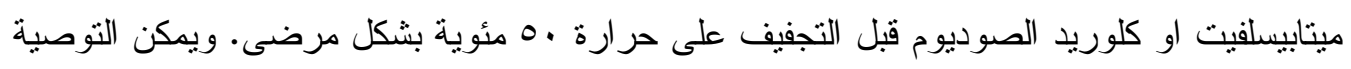

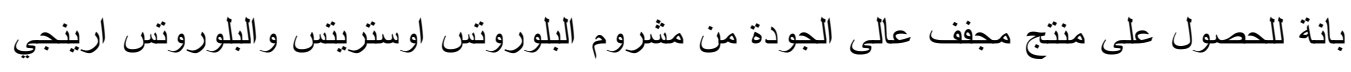

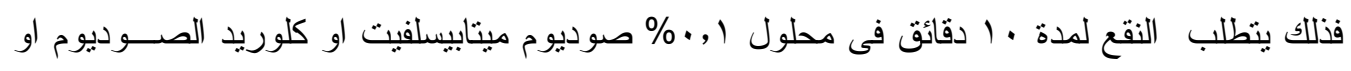
حتى حض الستريك و التجفيف على •0 درجة مئوية فقط لمنع التلون البنى و المحافظة على اللون

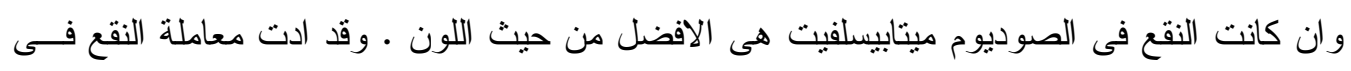

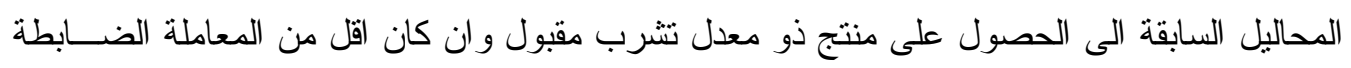

